\title{
Fiscal Policy and Public Debt Sustainability in Nigeria
}

\author{
Inibehe Nya \\ Regional Service Head, South- South/South- East, First City Monument Bank Limited \\ 80, Olu Obasanjo Road, Port Harcourt, Rivers State \\ Chukwuemeka O. Onyimadu* \\ National Institute for Legislative and Democratic Studies, National Assembly, Abuja
}

\begin{abstract}
The study investigated fiscal policy and public debt sustainability in Nigeria between 1990 and 2017, by employing an error correction model and IMF/World Bank debt burden indicators such as solvency and liquidity ratios. The results from IMF/World Bank debt burden indicators revealed that Nigeria's debt has been sustainable over the last 8- 10 years using the solvency ratios. Also, the liquidity indicator (debt service/export earnings) showed that Nigeria was able to meet its short term liabilities, as the debt burden indicators were below the indicative threshold of $20 \%$. On fiscal policy sustainability, the empirical result using cointegration test revealed that the fiscal variables were cointegrated, indicative of the fact that fiscal policy in Nigeria was sustainable. However, it was further revealed by Wald coefficient restriction test that although fiscal policy in Nigeria was sustainable, it was found to be weakly sustainable. Thus, Nigeria could introduced debt ceilings in order to prevent explosion of the initial stock of debt arising from arbitrary borrowings by state governments.
\end{abstract}

DOI: $10.7176 / \mathrm{JESD} / 10-19-02$

Publication date:October $31^{\text {st }} 2019$

\section{Introduction}

The growing challenge of high fiscal deficits and accelerating debt levels in most economies of the world, coupled with the debt crisis in the Eurozone area has more than ever, ignited global concerns from economists and policymakers towards a renewed focus on the sustainability of fiscal policy and public debts in both the developed and developing economies. The import of this is that deteriorating fiscal sustainability imposes some constraints on the growth and development of debtor nations and constitutes not only a drain on their resources but a drag on debt serviceability. Corroborating this assertion, Curtasu (2011) stated that unsustainable fiscal policies could worsen the macroeconomic conditions and make economies more vulnerable to exogenous shocks, adding that unsustainable fiscal policy could harm the welfare state through large fiscal deficits and excessive public debt stocks, generating an inefficient allocation of resources, an excessive public debt stock that could affect future generations, and an increase in the inflation rate and its volatility.

Over the years, Nigerian government has employed a blend of monetary and fiscal policies to achieve macroeconomic stability of the economy. Whereas monetary policies involve the process by which the monetary authority such as the Central Bank of Nigeria (CBN) controls money supply, with the aim of targeting inflation or interest rate to achieve price stability and enhance public confidence on our currency, fiscal policy measure on the other hand, is concerned with the use of government revenue realized through taxes and expenditure (spending on goods and services) to influence the economy. When the nation's revenue through taxes exceeds the expenditure, this result in fiscal surplus and on the contrary, when government spending exceeds revenue, the outcome is fiscal deficit and government is said to be running at a budget deficit. It is important to note that fiscal deficit may also result from government inefficiencies, reflecting widespread tax evasion or wasteful spending rather than a planned countercyclical policy.

Unarguably, fiscal deficits in Nigeria is not a new development as the country recorded her first fiscal deficit of N455.10 million in 1970, ten years after independence. Since then, the country has continued to be on a sustained path of deficit financing using the instrument of public debt. However, the growing concerns over Nigeria's debt problems started in the early 1980's when the country's foreign exchange earnings witnessed a marked drop induced by the falling prices of oil in the international market. This is more visible as Nigeria is a mono- product economy with heavy dependence on oil as a major revenue earner. 


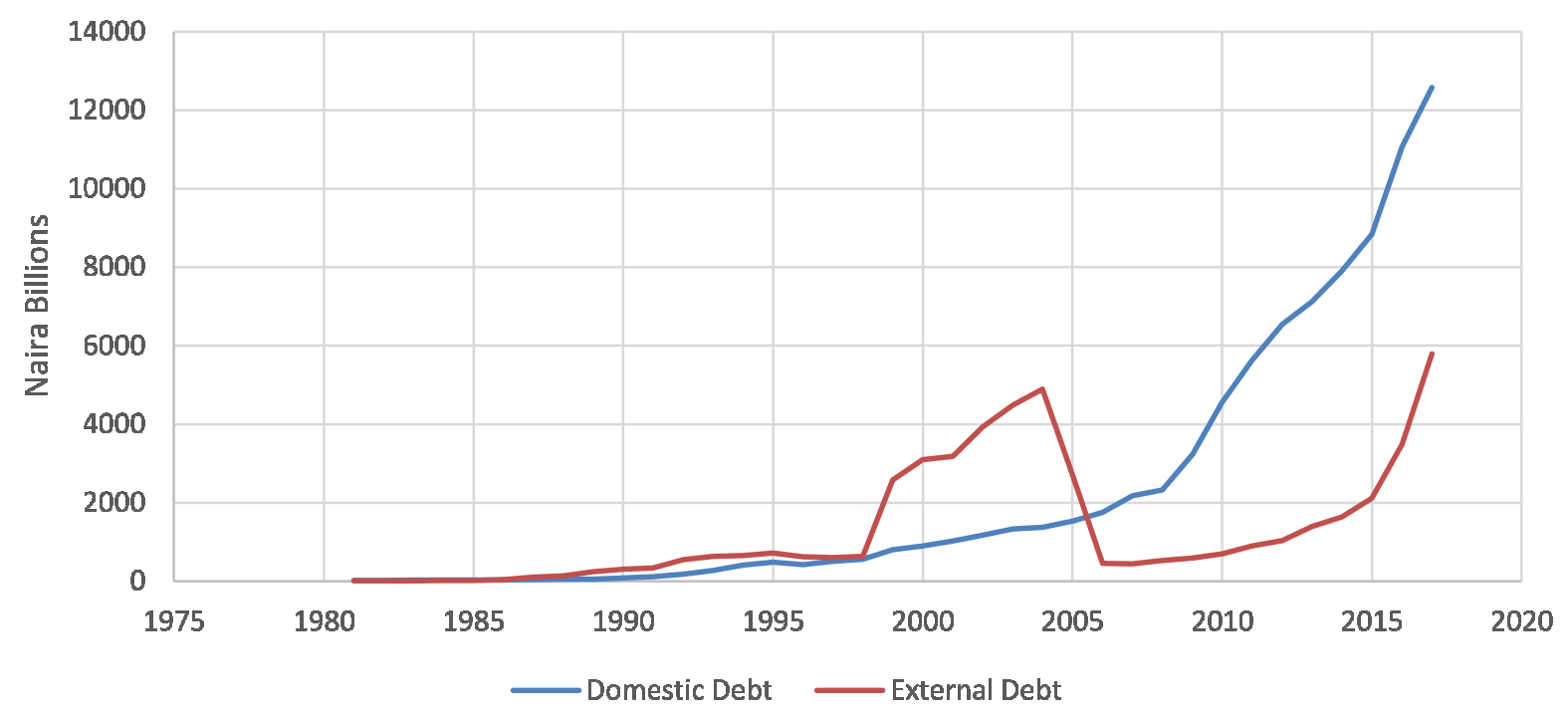

Figure1: Trend Analysis of Nigeria's Public Debt Outstanding (1990 - 2017)

Source: CBN Statistical Bulletin, 2017

Figure 1 shows the domestic and external debt mix for Nigeria in financing the fiscal deficits for the period 1990 - 2017. It is important to clarify that external debt refers to debt owed to foreign creditors such as multilateral agencies (the African Development Bank(ADB), the World Bank, or the Islamic Development Bank), to bilateral sources (such as the China Exim Bank, the French Development Bank or the Japense Aid Agency), or to private creditors like the investors in Nigeria's Eurobonds. Domestic debt on the other hand, refers to debt incured within Nigeria, usually through the issuance of bonds that will then be purchased by banks, pension funds and other domestic and foreign investors.

From Figure 1, Nigeria's domestic and external debt profile have been increasing progressively from 1990, with external debt forming the bulk of the debt stock. This implies that Nigeria depended much on external debt to fund her fiscal deficits and other expenditures up to 2005. However, the trend took a dramatic turn in 2006 as external debt declined sharply, from N2,695.07 trillion in 2005 to N451.46 billion in 2006, representing a decrease of about 83.25\%, while domestic debt rose from N1,525.91 trillion in 2005 to N1,753.26 trillion in 2006, about $14.90 \%$ increase. The decline in external debt stock may be explained by the Paris Club debt relief in 2006 which made Nigeria's obligation to foreign creditors in terms of debt service 'nose dive'. Another possible reason that could be adduced for this is that Ministry of Finance put in place a medium - term debt strategy with a mix of limited external and domestic borrowing that is considered appropriate for the economy. The strategic mix of limiting the country's external debt and increasing domestic borowing is considered appropriate based on the fact that external debt is subject to fluctuations in exchange rates, capable of affecting the nation's debt repayment and further exarcebating Nigeria's debt burden while domestic debt, which is denominated in local currency, is free from exchange rate fluctuations, thereby ensuring stability of the debt repayment programmes. The debt mix is evidenced from the trend analysis (figure 1) as domestic debt continued to lead external debt for the period 2006 $-2017$.

Deficit financing refers to the method employed by the government to finance its overall fiscal deficit. The financing option through borrowing is considered the best stimulant for the economy in the short run and in the long run, it constitutes a drag on the economy due to interest rate accrual. Aside from financing fiscal deficits through borowing from external and domestic sources, other options include quantitative easing $(\mathrm{QE})$ and withdrawal from the nation's reserves.

For the period under review(1990-2017),the Nigerian economy ran on budget deficit with exception of 1995 and 1996 where a marginal surplus of N1billion and N32billion were recorded respectively, as shown in Table 2. 
Table 1: Stylized Facts on Federal Government Fiscal Position1990- 2017(Naira Billions).

\begin{tabular}{|c|c|c|c|c|}
\hline Year & FGN Retained Revenue & Total Expenditure & Surplus(+)/Deficit(-) & $\%$ Surplus/Deficit of GDP \\
\hline 1990 & 38.15 & 60.27 & -22.1161 & -4.42608 \\
\hline 1991 & 30.83 & 66.58 & -35.7552 & -5.99874 \\
\hline 1992 & 53.26 & 92.8 & -39.5325 & -4.34517 \\
\hline 1993 & 126.07 & 191.23 & -65.1577 & -5.17506 \\
\hline 1994 & 90.62 & 160.89 & -70.2706 & -3.98628 \\
\hline 1995 & 249.77 & 248.77 & 1 & 0.03454 \\
\hline 1996 & 325.14 & 337.22 & 32.0494 & 0.848062 \\
\hline 1997 & 351.26 & 428.22 & -5 & -0.12161 \\
\hline 1998 & 353.72 & 487.11 & -133.3893 & -2.90672 \\
\hline 1999 & 662.59 & 947.69 & -285.1047 & -5.37187 \\
\hline 2000 & 597.28 & 701.06 & -103.7773 & -1.50457 \\
\hline 2001 & 796.98 & $1,018.03$ & -221.0489 & -2.71754 \\
\hline 2002 & 716.75 & $1,018.16$ & -301.4016 & -2.65968 \\
\hline 2003 & $1,023.24$ & $1,225.97$ & -202.7247 & -1.52407 \\
\hline 2004 & $1,253.60$ & $1,426.20$ & -172.6 & 1.275309 \\
\hline 2005 & $1,660.70$ & $1,822.10$ & -161.4 & 1.962283 \\
\hline 2006 & $1,836.61$ & $1,938.00$ & -101.3975 & 1.906336 \\
\hline 2007 & $2,333.66$ & $2,450.90$ & -117.2371 & 2.256042 \\
\hline 2008 & $3,193.44$ & $3,240.82$ & -47.3796 & 2.748049 \\
\hline 2009 & $2,642.98$ & $3,452.99$ & -810.0085 & 1.162932 \\
\hline 2010 & $3,089.18$ & $4,194.58$ & -1105.401 & -0.03727 \\
\hline 2011 & $3,553.54$ & $4,712.06$ & -1158.519 & 0.377862 \\
\hline 2012 & $3,629.61$ & $4,605.39$ & -975.7831 & 0.42768 \\
\hline 2013 & $4,031.83$ & $5,185.32$ & -1153.49 & 0.427273 \\
\hline 2014 & $3,599.63$ & $4,571.06$ & -835.678 & 0.364776 \\
\hline 2015 & $3,431.07$ & $4,988.86$ & -1557.793 & -0.42581 \\
\hline 2016 & $2,952.51$ & $5,160.74$ & -2208.222 & -2.76895 \\
\hline 2017 & $4,622.60$ & $8,302.10$ & -3679.5 & -2.21288 \\
\hline
\end{tabular}

Source: CBN Statistical Bulletin, 2017

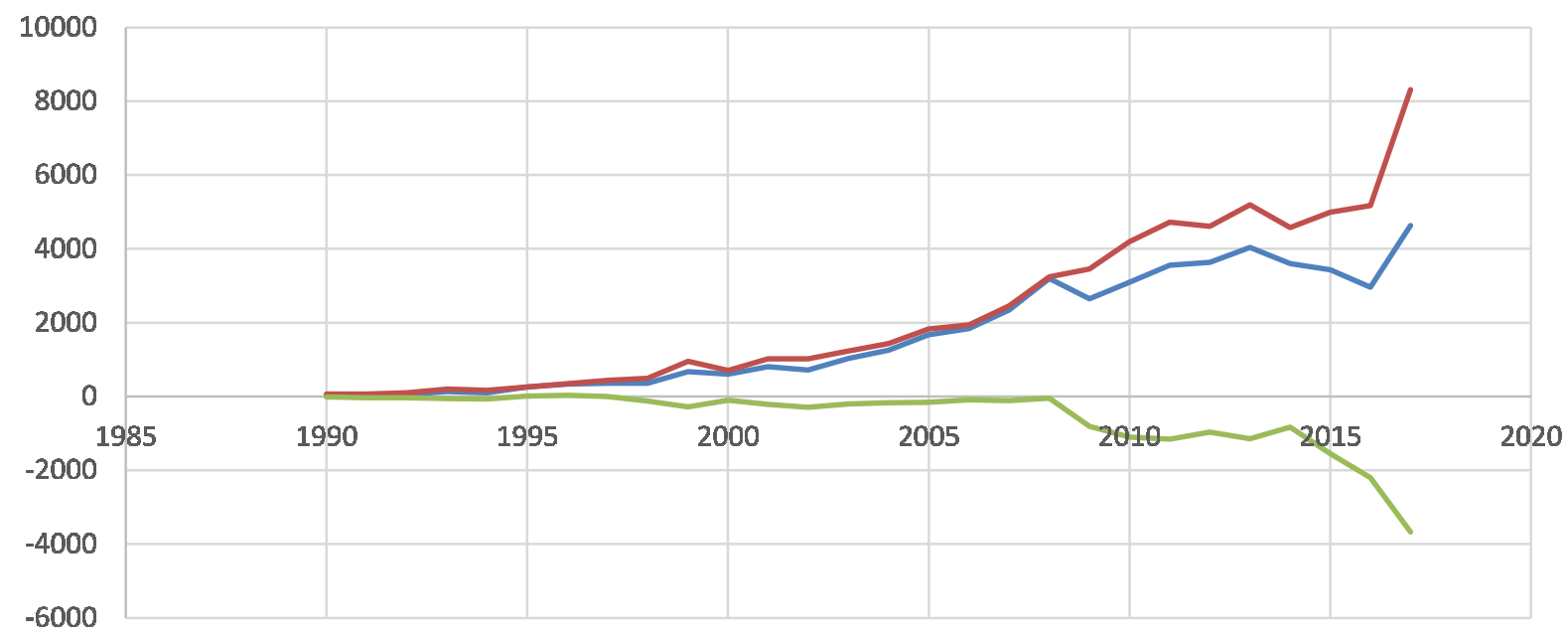

—FGN Retained Revenue — Total Expenditure —Surplus(+)/Deficit(-)

Figure 2: Trend Analysis of Federal Government Fiscal Position(1990 - 2017).

Source: CBN Statistical Bulletin, 2017 and Authors' compilation.

The persistent deficits had been majorly financed by government through borrowing from external or domestic sources as already explained, and ocassionally through the depletion of its reserves. Some of the projects financed by debt included Ajaokuta Steel Complex, Delta Steel Complex, Port Harcourt and Kaduna refineries. It is important to state that the Ajaokuta and Delta Steel Complexes, which were viewed as precursors for Nigeria's industrialization, were completely abandoned while the refineries operated at a very low capacity utilsation for 
reasons not compeletely alienated from avarice, corruption and erratic policy changes of the Federal Government.The failure of these laudable projects which would have ensured productive employment, poverty reduction and the positioning of the Nigerian economy on growth and development trajectory calls for questioning the omission or oversight of Debt Management Office(DMO) responsibilities, which amongst others, include that funds are borrowed from appropriate sources and applied prudentially with sound analytical and regulatory frameworks that will assure serviceability and amortisation of the country's debt as at when due. One explanation for this shortcoming is the fact that the roles assigned to Debt Management Office (DMO) were devoid of direct or oversight function of projects monitoring and evaluation $(\mathrm{M} \& \mathrm{E})$ to ensure funds are properly channelled to the purpose it was meant for, thus guranteeing debt payback or serviceability.

The option of quantitative easing $(\mathrm{QE})$ is not a recommended option for deficit financing in Nigeria and other developing countries based on the fact that these economies are consumption based and the application of this financing option could lead to higher inflation in the long run, due to increased money supply. According to Umo(1986), printing of money is highly inflationary as an increase in the volume of money is not matched by increase in production in the economy. He cited the case of some African countries like Uganda(under Idi Amin) and Congo Democratic Republic(under Mobutu Seseko) who printed money to balance their budget and this resulted in very high inflationary levels due to failure of the increased volume of money to match production of goods and services. Table 2 below shows the fiscal position of the Federal Government of Nigeria for the period 1990-2014. The deficits fluctuated over the years with a sharp deepening in 2010, 2011 and 2013 with corresponding values of N1.105 trillion, N1.158 trillion and N1.153 trillion respectively and later declined in 2014 to N971.43 billion. It is important to mention that fiscal deficits are certainly not new and perculiar to Nigeria alone but common characteristics of almost all countries of the world, including the developed economies of USA, United Kingdom.

From the IMF World economic Outlook, UK recorded the highest fiscal deficits of $10.85 \%$ of their GDP in 2009 , followed by USA with a deficit of $10.29 \%$ and $3.21 \%$ for Nigeria in the same year. This is an indication that even the developed economies run on fiscal deficits. On a comparative basis, Nigeria with a fiscal deficit to GDP of $3.21 \%$ is more sustainable compared to USA and UK with deficts to GDP of $-10.29 \%$ and $-10.85 \%$ respectively.

Nigeria's fiscal position suffered an imbalance in 1970 with the country recording her first fiscal deficit of N455 million. This development marked the beginning of the era of oil boom (1970s) and Nigeria's heavy dependence on oil as a major source of revenue at the detriment of the non-oil sector (agriculture, manufacturing, building and construction). However, fluctuations in oil prices in the international market led to budgetary deterioration which has continued to enmesh the country on a sustained path of deficit financing using the instrument of public debt. As the nation continued to experience unstable fiscal position, the result is a rising debt profile capable of throwing the country into a debt trap.

The motivation for this study is based on the fact that many of the studies that replete the extant literature in Nigeria's public finance focused attention on public debt and the bi-directional causality between public debt and deficit financing and other macroeconomic variables such as interest rates and growth dynamics. However, not much has been done on the sustainability of Nigeria's fiscal policy and public debt by analysts and those in the academia in order to validate the veracity or otherwise of the increasing public outcry, misinformation and misconception in the media and public debates, that Nigeria's economy is on the verge of collapse as a result of increasing public debt profile which has become unsustainable in the last decade.

This paper will be relevant to analysts and policy makers in the evolvement of strategies for sound fiscal policy and debt management that will ensure overall macroeconomic stability of the country. It will also assist to enlighten the public that rising public debt does not imply its unsustainability and the country being at the verge of collapse.

Therefore, the need to clarify Nigeria's fiscal policy and public debt sustainability position and possibly, provide a knowledge base for future debates has formed the major objective of this paper. The specific objectives are to examine whether Nigeria has exceeded her borrowing limit by carrying out a debt sustainability analysis, determine whether or not fiscal policies in Nigeria are sustainable by assessing the robustness or otherwise of Nigeria fiscal policies and finally, recommend policy options aimed at reducing the widening fiscal deficit gaps and ensure macroeconomic stability.

The rest of the paper is categorized as follows. Section two presents the theoretical and empirical literature while section three focuses on the methodology and data collection. Section four dwells on empirical result and discussion and finally, section five contains the recommendations and conclusion.

\section{Theoretical Background}

The theoretical discourse on fiscal and public debt sustainability is centered on the IMF/World Bank Debt Sustainability Framework and Present Value Budget Constraint (PBVC). The IMF/World Bank Debt Sustainability Framework (DSF) introduced in 2005 with subsequent reviews in 2009 and 2012, is a standardized framework for the analysis of public debt sustainability in Low Income Countries (LICs). It (DSF) defines debt 
sustainability as the capacity of a country to meet its current and future debt service obligations in full, without recourse to debt rescheduling or the accumulation of arrears and without compromising growth( IDA-IMF, 2004). The main thrusts of this framework are to provide guidance for LICs borrowing decisions, creditors' lending decisions and inform IMF and World Bank analysis and policy advice (IMF, 2013).

Under the World Bank's Country Policy and Institutional Assessment (CPIA), countries are classified on the basis of their CPIA index using four indicators namely economic management, structural policies, policies for social inclusion and equity, and public sector management and institutions. These countries are then rated based on these four performance criteria with the rating of one (1) being the lowest and six (6) the highest. The Debt Sustainability Framework (DSF) classifies countries using the CPIA index into three groups (low, medium and high performer) depending on the strength of countries policies and institutions as indicated in the indexes below. $\leq 3.25$ - weak policies and institutions (low performer).

$>3.25<3.75$ - medium policies and institutions (medium performer)

$\geq 3.75-$ strong policies and institutions (high performer)

Consequently, Nigeria is classified by IMF and World Bank as medium performer with a CPIA rating of 3.4.

Debt Sustainability Framework employs macroeconomic and debt data in assessing whether a country's debt is sustainable or not using debt burden indicators such as the solvency and liquidity positions: Debt Stock/GDP, Debt Stock/Export, Debt Stock/Revenue and Debt Service/Export. However, it is important to stress that thresholds assigned by the DSF are not static but vary from one LIC to another depending on the quality of their policies and institutions.

The Present Value Budget Constraint (PVBC), also called The Lender- Based Approach, states that government is considered to be solvent if the flow of expected value of future resources is at least equal to the face value of the stock of debt as indicated in the equation below:

$D_{0}=\sum_{t=1}^{\infty} \frac{\text { Pbal }_{t}}{(1+r)^{t}}$

Where $D_{o}$ is the initial stock of debt, Pbal $_{t}$ is the future primary balances (surpluses or deficits) and $(1+r)^{t}$ is the discounting factor.

The above equation is called the intertemporal budget constraint of government and it holds true with the assumption of Non-Ponzi game (NPG) by government. That is, government is not involved in rolling over its debt (bubble financing its expenditure) by issuing new debts to finance the deficits.

The PVBC/econometric approach employs the stationarity and co-integration tests in the evaluation of fiscal policy sustainability. While stationarity test is carried out using the Augmented Dickey Fuller (ADF) and Phillip Perron (PP), the co-integration test between government revenue and expenditure provides a necessary condition for fiscal policy sustainability analysis. Consequently, fiscal sustainability between the co-integrating vectors (expenditure and revenue) is achieved if the vectors are of order $I$ (1) and are co-integrated; at this point fiscal policies of government are considered sustainable (Hakkio and Rush, 1991).

However, the degree of sustainability of fiscal policy- whether strongly or weakly sustainable is further evaluated using Wald Coefficient Restriction Test. If the beta $(\beta)$ co-efficient of the independent fiscal variable is 1 , this implies a strong fiscal policy sustainability and conversely, beta co-efficient of less than 1 depicts a weak sustainability of government fiscal policy (Quintos, 1995).

Regarding the empirical literature, Corsetti and Roubini(1991) carried out a study on fiscal deficits, public debt and government solvency on 18 Organisation for Economic Co-operation and Development (OECD) countries, 1960 -1989, using stationarity tests( PP and ADF) found out major differences in long term sustainability of public debt across the OECD countries. The study revealed that major OECD countries like US, France, Germany, Japan, UK and Canada did not appear to have issues with public debt sustainability whereas, other smaller OECD countries like Greece, Netherlands, Belgium and Ireland were faced with debt sustainability problems, with a common large debt to GDP ratio. Corsetti and Robin failed to advance reason for the unsustainability of smaller OECD countries, however, this could be due to failure of OECD governments to achieve intertemporal budget constraints.

Makrydakis, Tzavalis and Balfoussias (1999) investigated Policy regime changes and long run sustainability of fiscal policy: An application to Greece. Using time series data between 1958 and 1995, the stationarity tests result showed that Greece debt was not sustainable as the government failed to satisfy intertemporal budget balance in the long run. The study associated the cause of the failure with Greece deterministic policy regime shift in 1979.

Curtasu (2011) in a study on How to access Public Debt sustainability: Empirical Evidence from Advanced European Countries, using annual data spanning 1970-2012. The empirical evidence using stationarity test(ADF), co-integration test(Johansen) and fiscal reaction function revealed that few of the countries such as Denmark, 
Finland, Netherlands and Sweden were not in danger of facing solvency risk in the future, as their sustainability of their fiscal position was generated by public debt ratio did not surpass the threshold and as well as by a primary surplus large enough to cover the stabilizer one(except the Netherlands).However, the study revealed that the rest of the countries such as France, Ireland, Italy, Portugal, Spain and UK were over-indebted and the credit markets were already concerned about their ability to service their debts, evidenced by their huge debt ratios and the fact that they also run primary deficits or very low surpluses, that cannot matched the primary balance-to-GDP ratio required to stabilize debt.

In a study on Sri Lanka carried out by Foneska and Ranasinghe (2007) on Sustainability of Sri Lanka's public debt using the traditional threshold ratios and the theoretical model approach to measure liquidity and solvency of the domestic and external debt, the result revealed that Sri Lanka failed to achieved the debt sustainability set by International agencies as all indicators exceeded the upper threshold limits. The study further argued that if such condition persists, the country will fall into a serious debt trap, and will not be able to source for funds from both domestic and foreign sources at affordable cost.

Adam (2003) investigated the Debt Servicing capacity of Nigeria's economy using survey method with DMO officials and the accounting measurement of debt to GDP ratio and argued that the Nigerian debt situation, to a greater extent, is highly unsustainable. According to the study, the unsustainability of Nigerian debt could be associated with high initial debt stock, high interest rate, lower real GDP growth, and large trade deficits. While the conclusion by Adam on Nigeria's debt being highly unsustainable may be partially correct as per external debt /GDP and debt/export ratios with values of 64.4 and 176.9 against international benchmark of 50 and 150 respectively, I consider this conclusion as hasty on the basis that his analysis revealed that Nigeria's debt was sustainable considering indicators such as external debt/revenue ratio of 173.9 against 250, external debt service/export with ratio of 9.8 against 15 and external debt service/revenue ratio of 9.1 against 20 .

Oyeleke and Ajilore (2014) investigated the sustainability of fiscal policy in Nigeria between 1980- 2010 using the Error Correction Model (ECM) with the objective of determining whether government has violated intertemporal government budget constraints. The study revealed that fiscal policy was weakly sustainable in Nigeria's economy. The study recommended improvement on tax revenue generation and other sources of income by government with restriction of her expenditure to growth enhancing projects.

Dayaratna-Banda and Priyadashanee (2014) carried out a study on the impact of government budget deficit on debt sustainability in Sri Lanka using time series data from 1960 to 2012. Accounting ratio analysis was employed to test the sustainability of government debt using debt to GDP ratio. Result of Augmented Dickey Fuller (ADF) and Phillips- Perron (PP) tests showed that debt ratios were non-stationary, implying the existence of an unsustainable debt outlook. Hence, they concluded that public debt in Sri Lanka was not sustainable and therefore, a switch is required from foreign debt to other sources of financing of fiscal deficit or deficit reduction.

Ozkaya (2013) in a study on public debt stock sustainability in nine selected Organisation for Economic Cooperation and Development (OECD) countries namely Ireland, Spain, Greece, Portugal, Italy, United Kingdom, France, Poland and Turkey using quarterly data from 1999 to 2010 (1999Q1- 2010Q1), employed the Stationarity test (unit root test) statistics such as Augmented Dickey Fuller(ADF), Phillip Perron and Kwiatkowski-PhillipsSchmidt-Shin(KPSS) and co-integration test in testing the sustainability of public debt in those OECD countries. The result of the econometric analysis revealed that five of the OECD economies like Ireland, Greece, Spain and Portugal were characterized by unsustainable debt policies, while the rest of the countries namely Italy, UK, France, Poland and Turkey had debt policies that were sustainable.

Elliot and Kearney (1998) employed the co-integration test in their study on the intertemporal government budget constraint and tests for bubble financing of fiscal deficits in Australia, using time series data between 1953 and 1987. The findings did not revealed any evidence of unsustainability of public debt in Australia. However, there was evidence that the Australian government financed the sustained primary deficits through seigniorage (quantitative easing) as shown by co-integration relationship between government spending and taxation plus seigniorage, with co-integrating coefficient of unity.

Payne (1997) carried out a study on International evidence on the sustainability of budget deficits of the G-7 countries (Canada, France, Germany, Italy, Japan, UK and US) between 1949 and 1994. Using the co-integration test, the study showed that in the case of Germany, for each dollar increase in expenditure, revenue increased by a corresponding amount. For France, Japan and Italy, the result showed that the budget deficits in these countries were not sustainable as evidenced by the absence of co-integrating relationship, whereas for UK, US and Canada, co-integration existed between revenue and expenditure, indicating sustainability of their budget deficits. On the overall, the study affirmed that the estimated coefficients on expenditures for the G-7 countries were significantly less than unity, an indication that government expenditure was growing faster than government revenue.

Employing the fiscal reaction function test, Bohn (1998) in his study of the behaviour of US public debt and deficits, examined the reaction of the US government towards the accumulation of public debt using annual data for the period 1916 - 1995. The paper showed that the U.S. government has historically responded to increases in the debt-GDP ratio by raising the primary surplus, or equivalently, by reducing the primary deficit. It further 
concluded that an estimated positive response of primary surplus to the debt-GDP ratio can be interpreted as a new test for the sustainability of U.S. fiscal policy, thus providing a strong evidence that U.S. fiscal policy has been sustainable in the sense of satisfying an intertemporal budget constraint for the sample period 1916-95 and various sub periods, despite the rather frequent primary budget deficits.

Ghosh, A.R, Mendoza, E.G, Ostry, J.D and Qureshi, M.S (2011) employed the fiscal reaction function test to examine whether 23 advanced economies possess space for fiscal maneuver, otherwise called fiscal space (defined as the difference between current debt level and a (country-specific) debt limit, where the latter is the debt level beyond which fiscal solvency fails) or whether they need urgent fiscal adjustment to achieve debt sustainability. The empirical evidence revealed a marginal response of primary balance to lagged debt which was nonlinear, assuming positive values at moderate debt levels and witnessed a decline when debt reaches 90-100\% of GDP. The findings also showed that while Australia, Korea, New Zealand and the Nordic countries have large fiscal space to handle fiscal shocks their economies, Greece, Italy and Japan and Portugal had the least space while UK, U.S, Spain, Ireland and Iceland were constrained in the degree of their fiscal maneuver.

Afonso (2000) employed stationarity tests (unit root tests) to examine stock of public debt and co-integration tests to examine the long run relationship between government expenditures and revenues for the period 19681997 among the EU countries. The empirical result revealed that most EU countries had unsustainable fiscal policies, with the exception of Austria, Germany and the Netherlands.

Stoian, Campeanu and Roman (2010) carried out a study on fiscal sustainability of Romania based on fiscal reaction function using quarterly data for the period 1995-2005. Using the ordinary Least Square (OLS) and fiscal reaction function to test the sustainability of fiscal policies in Romania, the result showed a weak fiscal sustainability in Romania.Smith and Zin (1991) carried out a study on the stationarity of public debt and fiscal deficits in Canada for the period 1946- 1984 and the empirical result showed that public debt in Canada was not sustainable.

\section{Model Specification.}

The assessment of debt sustainability using the IMF/World Bank approach involves the comparison of debt burden indicators with the indicative debt burden thresholds. Where the calculated debt burden indicator is greater than the indicative threshold, Nigeria is likely to face debt distress/unsustainability and conversely, where debt burden indicators are below the indicative threshold, the country may not experience distress in honouring her debt obligations as they fall due and her debt is deemed sustainable. The debt burden indicators (accounting ratios) are the solvency and liquidity ratios.

Solvency Ratios

The Solvency ratios measure the country's capacity to meet her long term debt liabilities. Examples of solvency ratios are:

\section{The Debt Stock- GDP Ratio}

This is the ratio of a country's debt stock expressed as percentage of her GDP (real). It measures the amount of the overall resources of a country available to repay its debt. The ratio is given as:

The threshold for debt stock /RGDP ratio is given as $40 \%$.

$$
\text { Debt Stock } / \text { RGDP } * 100 \%
$$

\section{Debt Stock- Export Ratio}

This is the ratio of a country's debt stock expressed as percentage of her export of goods and services for a particular year. An increasing debt to export ratio implies that debt stock is growing faster than the country's basic source of external income, indicating the country's likelihood of having problems to meet its debt obligations in the future.

It is expressed as:

$$
\text { Debt Stock } / \text { Export } * 100 \%
$$

The threshold for debt stock- export ratio is $150 \%$.

\section{Debt Stock- Revenue Ratio}

This is the ratio of a country's debt stock expressed as a percentage of its revenue. It measures the ability of government to generate fiscal resources to meet its debt obligations.

It is given as:

The threshold for debt stock- revenue ratio is $250 \%$.

$$
\text { Debt Stock } / \text { Revenue } * 100 \%
$$

Liquidity Ratio

This measures the ability of a country to meet its short term debt obligations as they fall due. A country's liquidity problems can be triggered by variables such as sharp drop in export earnings and tightening in global liquidity among others. An example of liquidity ratio is debt service to export ratio, expressed in terms of debt repayment as a percentage of export earnings. 


\section{Debt Service - Export Earnings ratio}

$$
\text { Debt Stock/Export Earnings * 100\% }
$$

The threshold for debt service to export earnings ratio is $20 \%$.

\section{The Econometric Approach:}

The econometric approach to fiscal policy sustainability makes use of annual time series data on the fiscal variables namely government revenue and expenditure, the later which also includes interest payments on public debt. In view of the trendy properties of time series data, it becomes important to overcome this problem by testing for the stationarity of the series, using the unit root tests such as the Augmented Dickey - Fuller (ADF) and the Phillips Perron (PP) statistics.

If the order of integration of the variables using ADF and PP tests reveals I(0), it means the series is stationary at levels, indicative of sustainable fiscal policies of government. However, if the variables are integrated of order one or two i.e. I(1) or I(2) and the vectors are co-integrated, fiscal policies are deemed sustainable whereas government fiscal policies are considered unsustainable if the variables are integrated of order one or two i.e. I(1) or I(2) and there is absence of co-integration between the fiscal variables.

Thus, the presence of unit root i.e. non stationarity of the variables of order one I(1) is a condition for the assessment of whether a long run relationship exists between the fiscal variables. The existence of long run relationship (co-integration) between government revenue and expenditure shows that government policies are sustainable. However, the degree of sustainability of fiscal policies is a function of whether the value of the parameter, beta $(\beta)$ is equal to unity (1) which denotes strong fiscal policy sustainability or less than one(1), which shows weak fiscal policy sustainability.

The model specification shows a functional relationship between government expenditure (GE) as the dependent variable and government revenue (GR) as the independent variable. This suggests that changes in government expenditure might be associated with changes in government revenue and the stochastic term. The control variables are inflation (inf) and population growth (pop).

$G E=f(G R, I N F, P o P)$

$G E=\alpha_{0}+\alpha_{1} I N F+\alpha_{2} P o P+e$

Where GE is Government Expenditure, GR is the Government Revenue, INF represents Inflation, PoP is Population Growth, $\alpha_{0}$ is a Constant, and $\alpha_{1}$ and $\alpha_{2}$ are parameters to be estimated with e representing the Stochastic term.

\section{Empirical Results}

\section{Total Debt Stock - GDP Ratio:}

Table 2 shows total debt stock to GDP ratio for 2005-2017.The data revealed that public debt in Nigeria seem sustainable as the calculated ratios were lower than the peer group threshold stipulated by IMF/World Bank. Although the ratio based on GDP are significantly lower than the peer group threshold (Figure 3), the GDP based ratios are rising and the shrinking the existing gap between from the peer group threshold. Thus, although GDP based ratios project Nigeria's Debt as sustainable, caution should be used in interpreting these findings. It is imperative to state that no country pays debt using its Gross Domestic Product (GDP), hence the importance of exploring other sustainability measures as suggested by export and revenues based ratios.

Table 2: Total Debt Stock/ GDP Ratio (GDP at 2010 Constant Prices)

\begin{tabular}{|l|l|l|}
\hline Year & TDS/GDP & Peer Group Threshold \\
\hline 2005 & $11.26 \%$ & $40.00 \%$ \\
\hline 2006 & $5.51 \%$ & $40.00 \%$ \\
\hline 2007 & $6.08 \%$ & $40.00 \%$ \\
\hline 2008 & $6.18 \%$ & $40.00 \%$ \\
\hline 2009 & $7.66 \%$ & $40.00 \%$ \\
\hline 2010 & $9.60 \%$ & $40.00 \%$ \\
\hline 2012 & $11.34 \%$ & $40.00 \%$ \\
\hline 2013 & $12.62 \%$ & $40.00 \%$ \\
\hline 2014 & $13.46 \%$ & $40.00 \%$ \\
\hline 2015 & $14.20 \%$ & $40.00 \%$ \\
\hline 2016 & $15.86 \%$ & $40.00 \%$ \\
\hline 2017 & $21.40 \%$ & $40.00 \%$ \\
\hline
\end{tabular}

Source: CBN Statistical Bulletin, 2017 


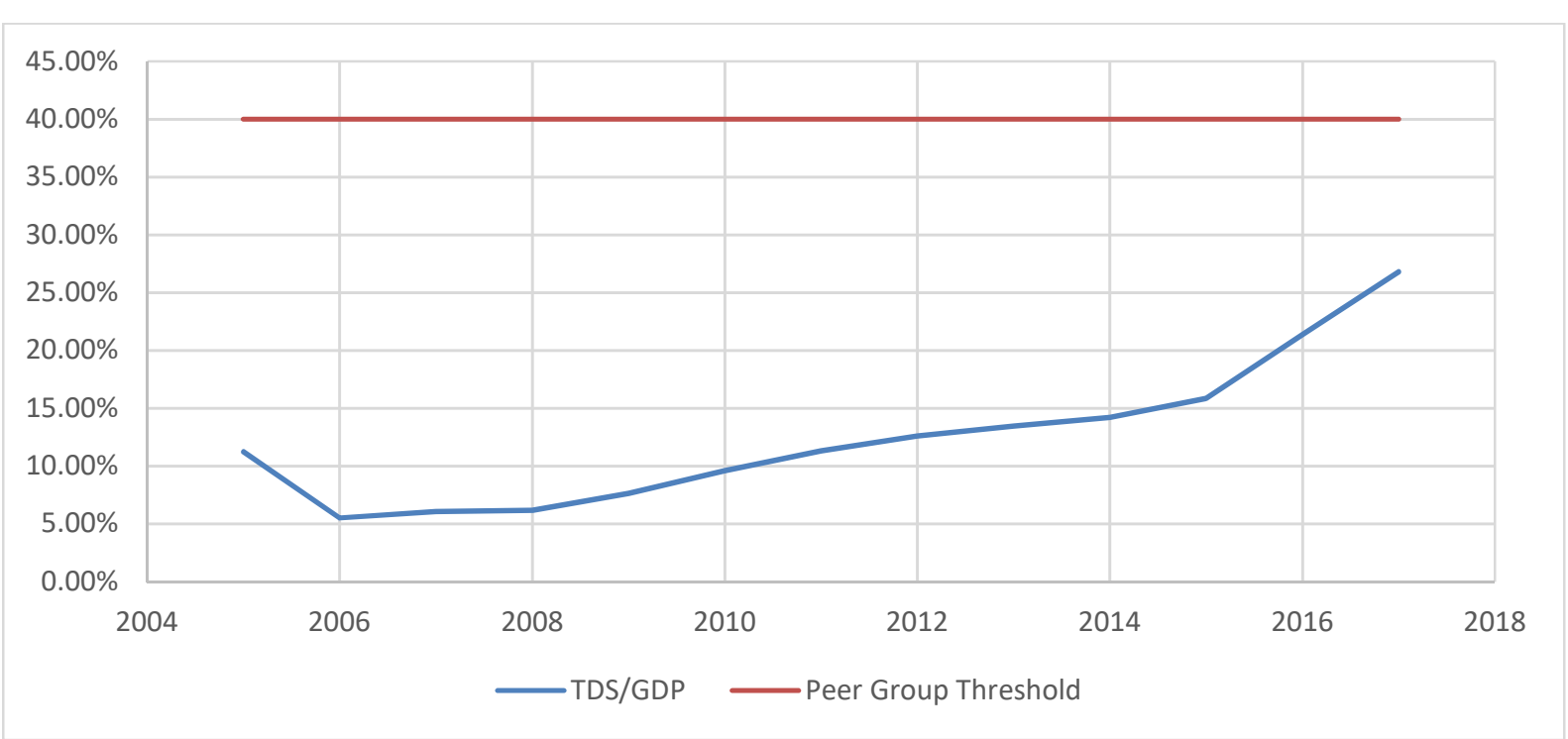

Figure 3: Graph of TDS/GDP Sustainability Analysis at 1990 Constant Prices

Source: CBN Statistical Bulletin, 2017

Debt Stock- Export Ratio:

Table 3 shows total debt stock to Export ratios for 2005-2017. The data revealed that public debt in Nigeria seems sustainable as the calculated ratios for total export and oil export, were lower than the peer group threshold stipulated by IMF/World Bank. Figure 4 shows that debt- export ratios from 2005 - 2015 remained consistently below the peer group threshold, suggesting sustainability. However, from $2016-2017$, the export based ratios were had crossed the peer group threshold. The unsuitable debt finding for $2016-2017$ period can be explained by the occurrence of economic recession, occasioned by the fall in world oil prices. In the recession period, Nigeria's total export fell by about $30 \%$ in 2015 - 2016, with oil and non -oil exports also falling by about $30 \%$ respectively. This exogenous shock affected Nigeria's exports negatively, thereby making the debt to export ratios to increase.

Also, from Figure 5, the Debt - Non - oil export ratios clearly indicates unsustainability. This ratio is important as it gives an idea of the degree of economic diversification Nigeria has attained. The ratio indicates the capacity of earnings from non - oil sources to meet debt obligations. Noticeably, without revenue from oil sources, Nigeria's current debt status would be highly unsustainable, as the Non - oil based ratios are evidently above the Peer group threshold.

Table 3: Debt Stock- Export Ratio

\begin{tabular}{|l|l|l|l|l|}
\hline Year & TDS/Export & TDS/Oil Export & TDS/Non-oil Export & Peer Group Threshold \\
\hline 2005 & $58.25 \%$ & $59.11 \%$ & $3983.71 \%$ & $150 \%$ \\
\hline 2006 & $30.10 \%$ & $30.66 \%$ & $1650.30 \%$ & $150 \%$ \\
\hline 2007 & $31.39 \%$ & $32.16 \%$ & $1309.12 \%$ & $150 \%$ \\
\hline 2008 & $27.37 \%$ & $28.83 \%$ & $540.75 \%$ & $150 \%$ \\
\hline 2009 & $44.37 \%$ & $47.11 \%$ & $762.37 \%$ & $150 \%$ \\
\hline 2010 & $43.64 \%$ & $46.38 \%$ & $737.27 \%$ & $150 \%$ \\
\hline 2011 & $42.79 \%$ & $45.52 \%$ & $713.70 \%$ & $150 \%$ \\
\hline 2012 & $49.97 \%$ & $53.05 \%$ & $860.25 \%$ & $150 \%$ \\
\hline 2013 & $55.74 \%$ & $60.19 \%$ & $752.66 \%$ & $150 \%$ \\
\hline 2014 & $73.57 \%$ & $79.42 \%$ & $1000.03 \%$ & $150 \%$ \\
\hline 2015 & $123.78 \%$ & $133.77 \%$ & $1657.16 \%$ & $150 \%$ \\
\hline 2016 & $164.53 \%$ & $177.74 \%$ & $2213.35 \%$ & $150 \%$ \\
\hline 2017 & $131.30 \%$ & $142.23 \%$ & $1708.65 \%$ & $150 \%$ \\
\hline
\end{tabular}

TDS is Total Debt Stock; PGT is Peer Group Threshold. Exp. is Export

Source: CBN Statistical Bulletin, 2017 


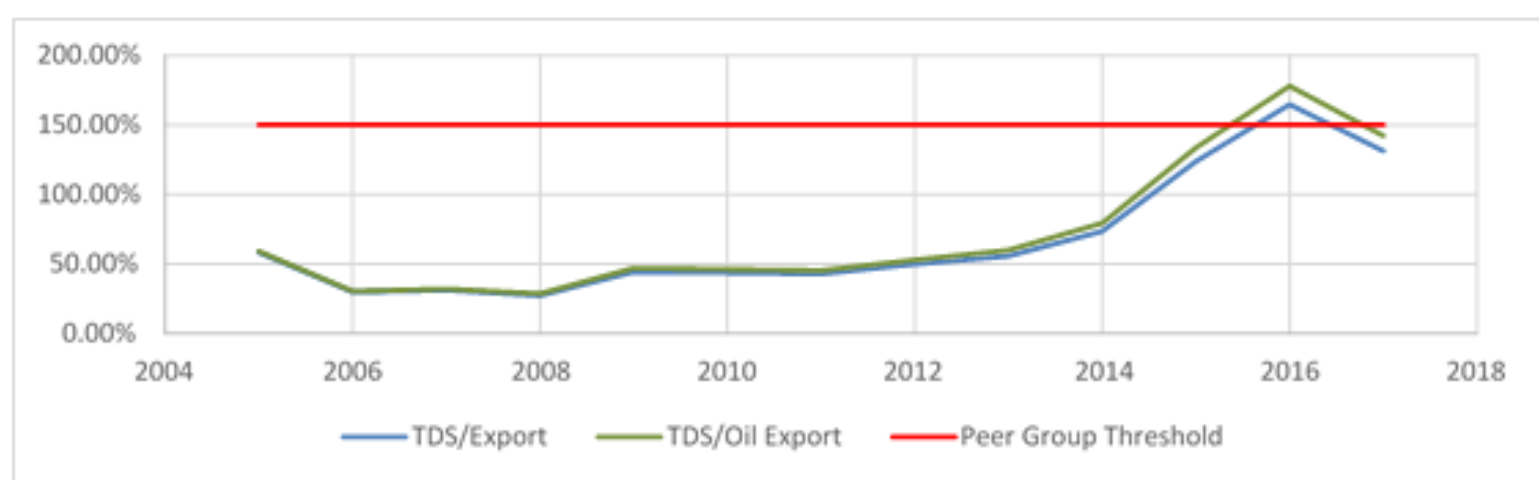

Figure 4: Graph of TDS/Export Sustainability Analysis Source: CBN Statistical Bulletin, 2017

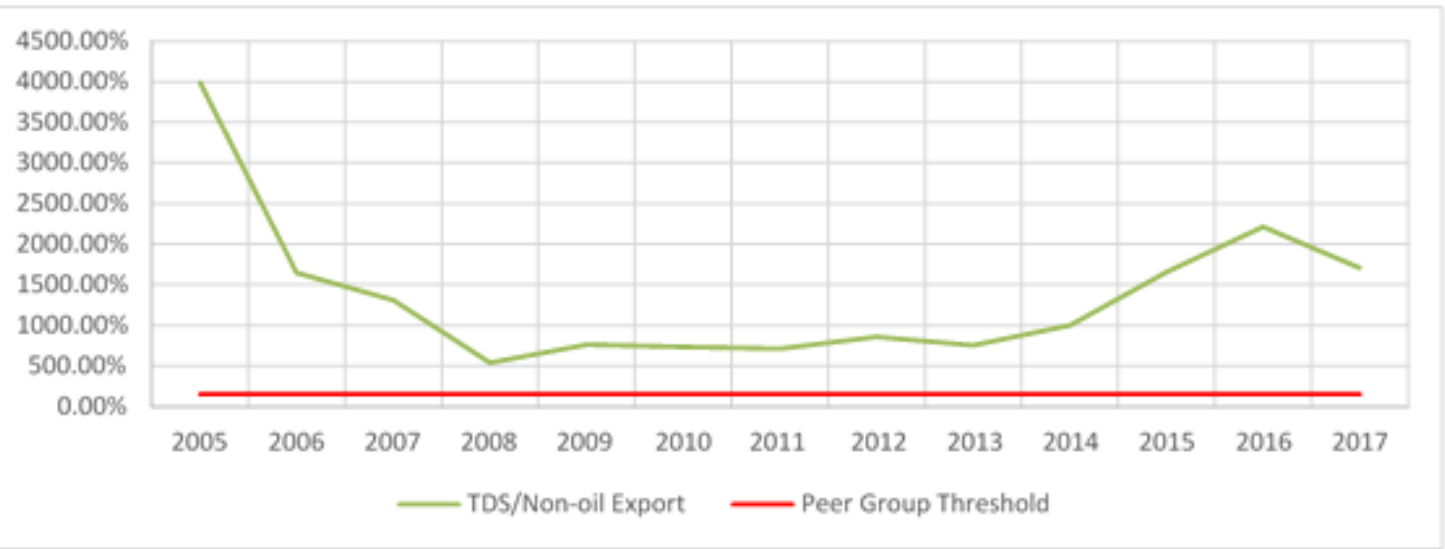

Figure 5: Graph of TDS/Non-oil Export Sustainability Analysis

Source: CBN Statistical Bulletin, 2017

\section{Debt Stock - Revenue Ratio:}

Debt stock - revenue ratio measures the country's fiscal capacity to generate resources to meet its debt obligations. The analysis in Table 4 revealed that, from 2005 - 2017, debt - revenue ratios, especially debt - Gross Federally Collected Revenue and Debt - Retained Revenue were lower than the peer group threshold of $250 \%$. However, from 2014, the debt - retained revenue ration had risen to $254.17 \%$ signaling that Nigeria could not generate enough revenue to pay its debt, an indication of fiscal indiscipline (Figure 6). Although the debt-revenue ratios prior to 2014 were sustainable, it is relevant to state that no country uses all its retained revenue to pay her debt obligations. Conversely, when revenue from oil and non - oil sources are considered (Figure 7), we can clearly see no improvements in fiscal responsibility and economic diversification, as the revenues generated from the non - oil sector can hardly meet debt obligations. From Figure 7 and Figure 8, debt - oil revenue ratio and debt retained revenue ratio would suggest debt sustainability but with increasing decadence in fiscal responsibility. 
Table 4: Debt Stock -Revenue Ratio

\begin{tabular}{|l|l|l|l|l|l|}
\hline Year & $\begin{array}{l}\text { TDS/GF } \\
\text { CR }\end{array}$ & $\begin{array}{l}\text { TDS/Retained } \\
\text { Revenue }\end{array}$ & $\begin{array}{l}\text { TDS/Oil } \\
\text { Revenue }\end{array}$ & $\begin{array}{l}\text { TDS/Non-oil } \\
\text { Revenue }\end{array}$ & $\begin{array}{l}\text { Peer } \\
\text { Threshold }\end{array}$ \\
\hline 2005 & $76.09 \%$ & $254.17 \%$ & $88.63 \%$ & $537.64 \%$ & $250 \%$ \\
\hline 2006 & $36.96 \%$ & $120.04 \%$ & $41.70 \%$ & $325.40 \%$ & $250 \%$ \\
\hline 2007 & $45.54 \%$ & $111.78 \%$ & $58.45 \%$ & $206.27 \%$ & $250 \%$ \\
\hline 2008 & $36.15 \%$ & $89.04 \%$ & $43.54 \%$ & $212.84 \%$ & $250 \%$ \\
\hline 2009 & $78.82 \%$ & $144.48 \%$ & $119.63 \%$ & $231.05 \%$ & $250 \%$ \\
\hline 2010 & $71.77 \%$ & $169.68 \%$ & $97.14 \%$ & $274.78 \%$ & $250 \%$ \\
\hline 2011 & $58.65 \%$ & $183.47 \%$ & $73.43 \%$ & $291.33 \%$ & $250 \%$ \\
\hline 2012 & $71.00 \%$ & $208.41 \%$ & $94.25 \%$ & $287.76 \%$ & $250 \%$ \\
\hline 2013 & $87.16 \%$ & $210.98 \%$ & $124.92 \%$ & $288.29 \%$ & $250 \%$ \\
\hline 2014 & $94.70 \%$ & $254.17 \%$ & $140.36 \%$ & $291.16 \%$ & $250 \%$ \\
\hline 2015 & $158.39 \%$ & $319.10 \%$ & $285.86 \%$ & $355.19 \%$ & $250 \%$ \\
\hline 2016 & $255.98 \%$ & $492.36 \%$ & $539.63 \%$ & $486.99 \%$ & $250 \%$ \\
\hline 2017 & $250.98 \%$ & $397.32 \%$ & $446.89 \%$ & $572.53 \%$ & $250 \%$ \\
\hline
\end{tabular}

Source: CBN Statistical Bulletin, 2017

GFCR refers to Gross Federally Collected Revenue

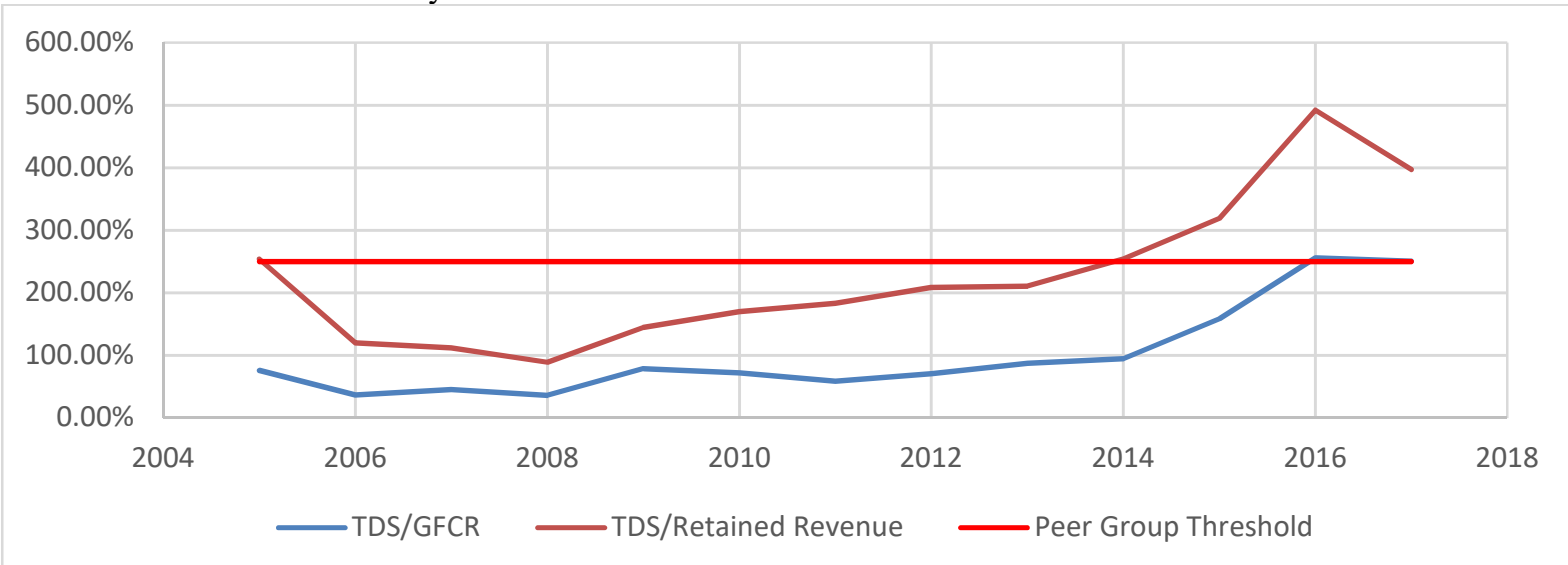

Figure 6: Graph of TDS/Revenue Ratio Sustainability

Source: CBN Statistical Bulletin, 2017

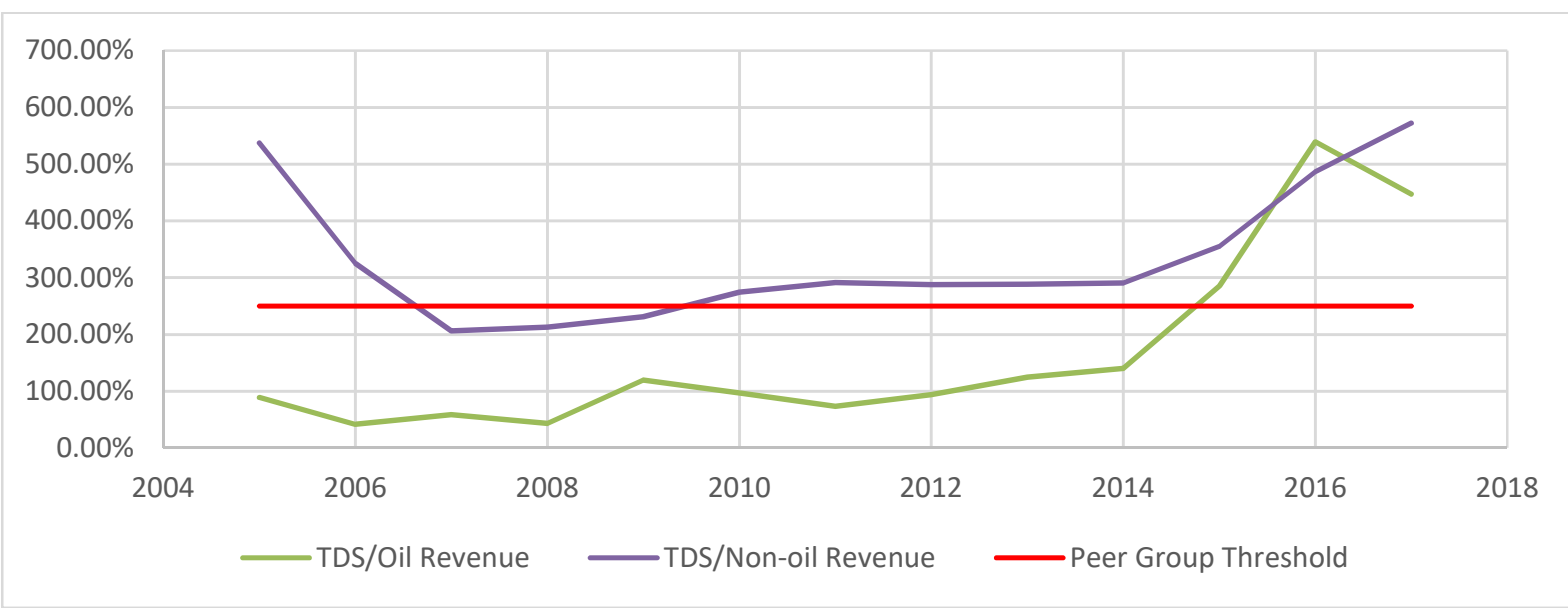

Figure 7: Graph of TDS/Oil and Non-oil Revenue Ratio Sustainability

Source: CBN Statistical Bulletin, 2017

\section{LIQUIDITY RATIO:}

Debt Service- Export Earnings Ratio:

The result of debt service - export earnings ratios (Table 5) for the review period revealed that Nigeria's debt service was sustainable for all the period under review, as the ratios were significantly lower than the prescribed threshold by IMF/World Bank for low income countries (LICs) (Figure 8). The implication of this is that the 
country has not experienced liquidity problems in servicing its debt for the stated period, implying enhanced capacity of the country to generate enough export proceeds to service its debt, hence its sustainability.

Table 5: Debt Service - Export Earnings Ratio

\begin{tabular}{|l|l|l|l|l|}
\hline Year & $\begin{array}{l}\text { Debt service to } \\
\text { exports (\%) }\end{array}$ & $\begin{array}{l}\text { Total debt service (\% of exports of goods, } \\
\text { services and primary income) }\end{array}$ & $\begin{array}{l}\text { Total debt service } \\
(\% \text { of GNI) }\end{array}$ & $\begin{array}{l}\text { Peer } \\
\text { Threshold }\end{array}$ \\
\hline 2005 & $15.41 \%$ & $15.41 \%$ & $5.41 \%$ & $20.00 \%$ \\
\hline 2006 & $10.98 \%$ & $10.98 \%$ & $2.90 \%$ & $20.00 \%$ \\
\hline 2007 & $1.44 \%$ & $1.44 \%$ & $0.38 \%$ & $20.00 \%$ \\
\hline 2008 & $0.48 \%$ & $0.76 \%$ & $0.21 \%$ & $20.00 \%$ \\
\hline 2009 & $0.73 \%$ & $1.28 \%$ & $0.27 \%$ & $20.00 \%$ \\
\hline 2010 & $0.38 \%$ & $1.50 \%$ & $0.37 \%$ & $20.00 \%$ \\
\hline 2011 & $0.34 \%$ & $0.51 \%$ & $0.14 \%$ & $20.00 \%$ \\
\hline 2012 & $0.25 \%$ & $1.34 \%$ & $0.31 \%$ & $20.00 \%$ \\
\hline 2013 & $0.40 \%$ & $0.49 \%$ & $0.10 \%$ & $20.00 \%$ \\
\hline 2014 & $0.31 \%$ & $5.32 \%$ & $0.83 \%$ & $20.00 \%$ \\
\hline 2015 & $0.51 \%$ & $2.85 \%$ & $0.30 \%$ & $20.00 \%$ \\
\hline 2016 & $0.93 \%$ & $6.31 \%$ & $0.63 \%$ & $20.00 \%$ \\
\hline 2017 & $0.74 \%$ & $6.83 \%$ & $0.98 \%$ & $20.00 \%$ \\
\hline
\end{tabular}

Source: CBN Statistical Bulletin, 2017

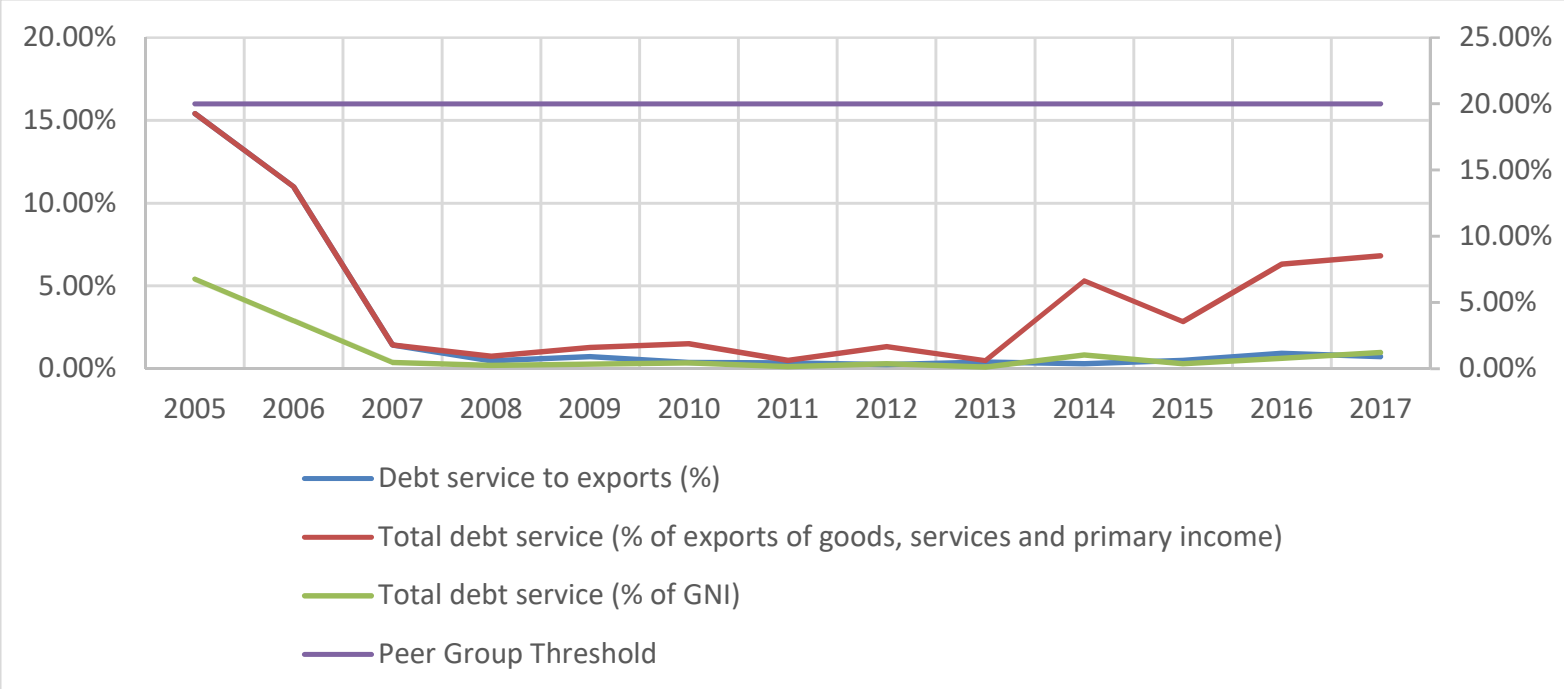

Figure 8: Graph of DS/Export Ratio Sustainability

Source: CBN Statistical Bulletin, 2017

Fiscal Sustainability Analysis:

Stationarity Test:

Table 6: Result of Unit Root Test:

\begin{tabular}{|c|c|c|c|c|c|c|}
\hline Variable & \multicolumn{2}{|c|}{ ADF } & \multicolumn{2}{c|}{ PP } & \multicolumn{2}{c|}{ Conclusion } \\
\hline & 1 ST DIFF & 2ND DIFF & 1 ST DIFF & 2ND DIFF & ADF & PP \\
\hline GE & 2.388 & $6.168^{*}$ & $4.960^{*}$ & - & $I(2)$ & $I(1)$ \\
\hline
\end{tabular}

* represents stationarity at $1 \%$ significance level based on MacKinnon critical value.

Source: Computed by Author

The result of the Unit Root test revealed the presence of unit root in the fiscal variables- government expenditure (GE) and government revenue (GR). Using ADF, the variables were integrated of order two, that is, stationary at second difference I(2), while stationarity was achieved between the two variables at first difference, I(1) when PP was applied. Following Leachman and Francis (2000), the presence of long run relationship will attest to the sustainability of fiscal policy. This was carried out using the Johansen co-integration test and the result is as shown in table 6 below: 
Table 7: Johansen Co-integration Test:

\begin{tabular}{|l|}
\hline Series: GE GR INF POP \\
\hline Lags interval (in first differences): 1 to 1 \\
\hline Unrestricted Cointegration Rank Test (Trace) \\
\hline
\end{tabular}

Unrestricted Cointegration Rank Test (Trace)

\begin{tabular}{|c|c|c|c|c|}
\hline Hypothesized & & Trace & 0.05 & \\
\hline No. of CE(s) & Eigenvalue & Statistic & Critical Value & Prob.** \\
\hline None $*$ & 0.678822 & 54.30103 & 47.85613 & 0.0110 \\
\hline At most 1 & 0.435612 & 28.17852 & 29.79707 & 0.0759 \\
\hline At most 2 & 0.381977 & 15.02222 & 15.49471 & 0.0588 \\
\hline At most 3 $*$ & 0.157945 & 3.953937 & 3.841466 & 0.0468 \\
\hline
\end{tabular}

Trace test indicates 1 cointegrating eqn(s) at the 0.05 level

$*$ denotes rejection of the hypothesis at the 0.05 level

**MacKinnon-Haug-Michelis (1999) p-values

Source: Computed by Author

The co-integration test revealed that the fiscal variables are co-integrated and this confirms the presence of long run relationship between government expenditure and government revenue, an indication of the fact that fiscal policy in Nigeria is sustainable (Table 7). Sustainability of fiscal policy is achieved if either government expenditure or government revenue does not drift away over the long run. The implication of this is that government expenditure and revenue can drift apart from equilibrium for a while over the short run, but economic forces and /or fiscal policy (government action) can bring the variables back over the long run( Oyeleke and Ajilore, 2014).

Although the study revealed that fiscal policy in Nigeria is sustainable, it is imperative to determine the degree of sustainability, i.e. whether fiscal policy in Nigeria is strongly sustainable or weakly sustainable. Quintos (1995) alluded that the degree of fiscal policy sustainability can be determined by testing for the statistical significance of the co-efficient $(\beta)$ of the independent variable. He concluded that a beta co-efficient of one $(\beta=1)$ denotes a strong fiscal policy sustainability while beta co-efficient of less than one $(\beta<1)$ shows a weakly sustainable fiscal policy.

In order to determine the strength of fiscal policy in Nigeria, Wald Co-efficient restriction test was employed to assess whether the co-efficient of the regressor (government revenue) was statistically different from 1 . The result of the Wald Co-efficient Restriction Test is as shown in table 8.

Table 8: Wald Co-efficient Restriction Test.

\begin{tabular}{|c|c|c|c|}
\hline \multicolumn{2}{|l|}{ Wald Test: } & \multicolumn{2}{|c|}{ Null Hyp: $\beta=1$} \\
\hline \multicolumn{3}{|c|}{ Equation: GE c GR } & \\
\hline Test Statistic & Value & df & Probability \\
\hline t-statistic & 7.145208 & 23 & 0.0000 \\
\hline F-statistic & 51.05400 & $(1,23)$ & 0.0000 \\
\hline Chi-square & 51.05400 & 1 & 0.0000 \\
\hline \multicolumn{4}{|c|}{ Null Hypothesis: $C(2)=1$} \\
\hline \multicolumn{4}{|c|}{ Null Hypothesis Summary: } \\
\hline \multicolumn{2}{|c|}{ Normalized Restriction $(=0)$} & Value & Std. Err. \\
\hline \multicolumn{2}{|l|}{$-1+C(2)$} & 0.247314 & 0.034613 \\
\hline
\end{tabular}

Source: Computed by Author

The result of the Wald Test rejects the null hypothesis that beta $(\beta)$ is statistically equal to 1 at $1 \%$ level of significance. The test revealed that the explanatory variable (GR) has a $\beta$ co-efficient of 0.25 i.e. $0<\beta<1$. The implication of this is that although fiscal policy in Nigeria is sustainable, it has been found to be weakly sustainable.

Error Correction Model (ECM):

After establishing the presence of co-integration between the fiscal variables, it is therefore important to run the Error Correction Model (ECM), which shows a short run dynamic relationship between the dependent variable (government expenditure) and the regressor (government revenue). The ECM term indicates the speed of adjustment of the dependent variable (GE) to restore or return to equilibrium, after a change in the explanatory variable (GR) or following an exogenous shock. The result of the ECM is as shown in table 9. 
Table 9: Error Correction Model (ECM)

\begin{tabular}{|l|r|r|r|r|}
\hline Dependent Variable= GE & \multicolumn{5}{|l|}{} \\
\hline Variables & Co-efficient & Standard Error & t- Statistics & Prob. \\
\hline C & -0.141816 & 0.079155 & -1.791625 & 0.0965 \\
\hline LOG GR & 0.592292 & 0.097897 & 6.050156 & 0.0000 \\
\hline ECM-1 $_{-1}$ & -0.000151 & 0.0000523 & -2.8777 & 0.0129 \\
\hline
\end{tabular}

Source: Computed by Author

The error correction model (ECM) coefficient therefore, is an indication of how quickly the fiscal variables (GE and GR) converge to equilibrium and for this to occur; the coefficient must be statistically significant, with the correct negative sign. Following from this, the ECM result showed that the coefficient is statistically significant at $5 \%$, with value of -0.000151 which was rightly signed. The implication of this is that the degree to which the fiscal variables will return to long run equilibrium after an exogenous shock will be very sluggish, further stressing the fact that only $0.02 \%$ disequilibrium between the fiscal variables (GE and GR) in the Nigeria macroeconomy was restored on a yearly basis as a result of extraneous shocks. Evidently, log GR which represents the elasticity of government revenue to changes in government expenditure, has a value of 0.59 less than 1 , thus further corroborating the result of the Wald Test that fiscal policy in Nigeria is weakly sustainable.

\section{Conclusion}

The study investigated fiscal policy and public debt sustainability in Nigeria between 1990 and 2017, by employing econometric techniques such as unit root test, cointegration test, error correction model, Wald restriction coefficient test and IMF/World Bank debt burden indicators such as solvency and liquidity ratios.

The results from IMF/World Bank debt burden indicators revealed that Nigeria's debt was sustainable in the last 8- 10 years using the solvency ratios (Debt Stock/Revenue and Debt Stock/Export), as the debt burden indicators were less than the indicative thresholds, thus implying Nigeria's ability to meet its long term debt liabilities. Also, the liquidity indicator (debt service/export earnings) showed that Nigeria was able to meet its short term liabilities, as the debt burden indicators were below the indicative threshold of $20 \%$. The findings were contrary to public outcry and misinformation that the Nigerian economy is not only strangulated by mammoth debt but also at the verge of collapse as a result of her rising debt profile which has become unsustainable.

On fiscal policy sustainability, the empirical result using cointegration test revealed that the fiscal variables (GE and GR) were cointegrated, indicative of the fact that fiscal policy in Nigeria was sustainable. However, it was further revealed by Wald coefficient restriction test that although fiscal policy in Nigeria was sustainable, it was found to be weakly sustainable, as shown by a beta coefficient of $0.25(0<\beta<1)$. This is in tandem with the findings of Oyeleke and Ajilore (2014).

The ECM coefficient of -0.000151 or $0.02 \%$ which represents the rate at which the fiscal variables are restored on a yearly basis as a result of exogenous shocks to the economy was considered very low and the rate of adjustment sluggish, thus pointing to the fact that central government must streamline expenditure to its revenue and diversify the economy by fully investing in the non-oil sector (export) in order to improve fiscal policy sustainability and macroeconomic stability of Nigeria.

Nigeria's weak fiscal stance is already a source of concerns and needs to be addressed to avoid fiscal crisis. On the basis of this, the following recommendations are proffered:

- Debt is a development tool. Hence, Nigeria could go ahead and borrow internationally to finance productive investment projects. However, these borrowings should be long term and have lower cost implications in terms of debt servicing. Also, borrowed funds should be tied to development projects that could either, reduce the country's dependence on foreign exchange or improve foreign exchange earnings.

- Government should introduced debt ceilings in order to prevent explosion of the initial stock of debt arising from arbitrary borrowings by state governments.

\section{References}

Afonso, A. (2000). Fiscal Policy Sustainability: Some Unpleasant European Evidence. ISEG Working Paper No. 12/2000/DE/CISEP, August.

Arrau, P. (1990). How Does the Debt Crisis Affect Investment and Growth? International Economics Department, World Bank.

Bernheim, D.B. (1989). A Neoclassical Perspective of Budget Deficit, Journal of Economic Perspectives, vol.3 no.2, spring, pp 55-72.

Bohn, H. (1998). The Behavior of US Public Debt and Deficits. The Quarterly Journal of Economics, Vol. 113, No.3.

Corsetti, G. and Roubini, N. (1991). Fiscal Deficits, Public Debt, and Government Solvency: Evidence from OECD Countries. NBER Working Paper, No.3658.

Curtasu, A.R (2011). How to Assess Public Debt Sustainability: Empirical Evidence for the Advanced European 
Countries. Romanian Journal of Fiscal Policy, Vol. 2, Issue 2, July - December, pp 20-43.

Dayaratna-Banda, O.G and Priyadashanee, A.A.S (2014). Sustainability of Government Debt in Sri Lanka. Sri Lanka Economic Journal, 5(1):51-69.

Elliot G. and Kearney C. (1988). The Intertemporal Government Budget Constraint and Tests for Bubbles. Research Discussion Paper, No. 8809, Reserve Bank of Australia.

Foneska A.T and Ranasinghe, S.S (2007). Sustainability of Sri Lankan's Public Debt. Sri Lankan Journal of Management, Vol. 12 Nos. 3\& 4 (July - December), pp.185-212.

Goldstein, M (2003). Debt Sustainability, Brazil and the IMF. Institute of International Economics, WP 03-1.

Ghosh, A.R, Mendoza, E.G, Ostry, J.D and Qureshi, M.S (2011). Fiscal Fatigue, Fiscal Space and Debt Sustainability in Advanced Economies. NBER Working Paper, No. 16782.

Hakkio C.S. and Rush M. (1991), "Is the Budget Deficit too Large?” Economic Inquiry, 29, 429-445.

Ijioma, E (2013).Nigeria: Fiscal Responsibility and Challenges of Economic Development, All Africa Global Media.

Leachman L. and Francis B. (2000). "Multi-Cointegration Analysis of the Sustainability of Foreign Debt." Journal of Macroeconomics, 22, (2): 207-227.

IMF (2002). Assessing Sustainability. Policy Development and Review Department.SM/02/166.

IMF (2013).Staff Guidance Notes on the Application of the Joint Bank-Fund Debt Sustainability Framework for Low Income Countries, November 5.

IMF-IDA (2004). Debt Sustainability in Low Income Countries - Proposal for an Operational Framework and Policy Implications. Washington, DC.

Makrydakis, J.S, Tzavalis, E and Balfoussias, A. (1999). Policy Regime Changes and Long Run Sustainability of Fiscal Policy: An Application to Greece. Economic Modelling, Vol.16, Issue 1, pp.71-86.

Oyeleke, O.J and Ajilore, O.T (2014). Analysis of Fiscal Deficit Sustainability in Nigeria Economy: An Error Correction Approach. Asian Economic and Financial Review.4(2):199-2010.

Ozkaya, A.(2013). Public Debt Stock Sustainability in Selected OECD Countries, Central Bank Review, Vol. 13, pp31- 49.

Payne, J. (1997). International Evidence on the Sustainability of Budget Deficits. Applied Economic Letters, No.12.

Quintos, E.C., 1995. Sustainability of the fiscal process with structural shifts. Journal of Business and Economic Statistics, 13(4): 409-417.

Smith, G.W. and Zin, S.E. (1991), "Persistent Deficits and the Market Value of Government Debts," Journal of Applied Econometrics, 6, 31-44.

Stoian, A, Campeanu, E. and Mihai, R.( 2010). Fiscal Sustainability based on Fiscal Reaction Function: Case Study of Romania. Finance a úvěr-Czech Journal of Economics and Finance, No.6.

Tesic, A; Ilic, D and Delic, T. (2014). Consequences of Fiscal Deficit and Public Debt In Financing the Public Sector. Economics of Agriculture 1/2014, UDC 336.14: 336.13.

Umo, J.U (1986). Economics: An African Perspective. Millennium Text Publishers Limited, $2^{\text {nd }}$ edition. 